\title{
Protecting Linguistic and Religious Minorities: Looking for Synergies among Legal Instruments
}

\author{
Eduardo J. Ruiz Vieytez
}

Citation: Ruiz Vieytez, Eduardo J. 2021. Protecting Linguistic and Religious Minorities: Looking for Synergies among Legal Instruments. Religions 12: 706. https://doi.org/ 10.3390/rel12090706

Academic Editors: Silvio Ferrari, Roberta Medda-Windischer and Kerstin Wonisch

Received: 15 July 2021

Accepted: 23 August 2021

Published: 31 August 2021

Publisher's Note: MDPI stays neutral with regard to jurisdictional claims in published maps and institutional affiliations.

Copyright: (C) 2021 by the author. Licensee MDPI, Basel, Switzerland. This article is an open access article distributed under the terms and conditions of the Creative Commons Attribution (CC BY) license (https:// creativecommons.org/licenses/by/ $4.0 /)$.
Human Rights Institute, University of Deusto, 48014 Bilbao, Spain; ejruiz@deusto.es

\begin{abstract}
Language and religion are two main cultural markers of collective identities and articulating factors at play in the majority-minority game. However, from a legal and political point of view, language and religion work very differently as factors for determining minorities. This is due, on the one hand, to their different connection with public bodies and, on the other hand, to the different role played by the two identity markers, more substantive in the case of religion and more instrumental in the case of language. Different forms of protection of linguistic and religious diversity and minorities have been developed so far. The two fields of protection have evolved separately and there has hardly been any dialogue between them. This article aims to analyze whether and how the usual forms of protection of linguistic diversity and linguistic minorities can be useful for the management of religious-based diversity or minorities. In this respect, linguistic diversity management draws more inspiration from religious diversity management techniques than the reverse. Nevertheless, a number of techniques that have been applied to the linguistic diversity protection may also play a potential role for the protection of religious diversity, opening the door to further synergies among legal instruments.
\end{abstract}

Keywords: religious diversity; linguistic diversity; minorities; language; religion; accommodation; human rights

\section{Introduction}

The purpose of this article is to determine whether and how the usual forms of protection of linguistic diversity and linguistic minorities can be useful for the management of religious-based diversity or minorities. To date, language and religion have been little studied as related identity factors, and their respective legal dynamics have received even less attention. The analysis of each has evolved separately and there has hardly been any dialogue between them.

This paper aims to partly cover this gap in legal studies from a comparative approach, which can subsequently leave room for further, more focused research. To achieve this, I will first describe the similarities and differences between language and religion in terms of collective identity dynamics, and the different role that each of them plays in the legal sphere today. I will later argue that the management of religious diversity poses a much more difficult challenge than linguistic diversity in the long term. The legal techniques or instruments commonly used for the management of each type of diversity will be discussed later. The main thesis will be that linguistic diversity management draws more inspiration from religious diversity management techniques than the reverse. However, the purpose of this article is to determine whether some of the usual means of protection of linguistic diversity may be beneficial for religious minorities.

\section{Language and Religion as Primary Identity Factors: Differences and Similarities}

Languages and religions have been the two main cultural markers of collective identity in the history of humankind, particularly in Europe and the Western world. Ethnicity can be added as another relevant marker, but it frequently overlaps with religious or 
linguistic differences and it is more difficult to define when it has to be referred to concrete cultural elements (Ruiz Vieytez 2016). A few decades ago, membership in a nation-state became as strong as the aforementioned markers. Although the state became widespread as the dominant majority-shaping political form at a late stage on other continents, today it operates as the most solid worldwide identity marker. Yet language and religion have played a fundamental, possibly exclusive role in the configuration of state-and therefore, national-identity. Only in cases where state divisions cannot be easily justified by linguistic or religious differences (such as in Latin America) have historical or geographical elements been invoked as additional markers to complete the respective social imaginaries.

Thus, language and religion are two main articulating cultural factors at play in the majority-minority game. This does not imply that cultural diversity conflicts are entirely based on language or religion, but that one of these two strong elements of identity affiliation is always found among the interacting groups. 'Religion and language are to be considered as anthropological constants in the evolution of mankind' (Darquennes and Vandenbussche 2011, p. 5). Indeed, religion is 'the primary evolutionary universal' within 'the human capacity to create and transmit culture', and, in order to 'operate effectively', religion 'must be implemented in action systems and must therefore involve communication via the secondary primary evolutionary universal, language (Williams 1992, p. 53). From a regulatory approach, language and religion are also the two most cited items in the legal definitions of the concept of minority, both nationally and internationally (Ruiz Vieytez 2016).

From a diachronic perspective, the strength of both factors in the singularisation of groups has been unequal in different periods throughout history. At the beginning of the Modern Age, religion was the main identity factor of Europeans. This would be exacerbated by the Reformation that, at the same time, would help to gradually strengthen the triumph of nation states, which would later identify themselves around primarily linguistic criteria ${ }^{1}$. With the passage of time, national identities in Europe were mainly underpinned by languages, increasingly displacing the importance of religious differences. The nineteenth century extolled national and linguistic differences and oriented the fight against diversity towards the linguistic realm to the detriment of the religious realm. With the parallel process of the secularisation of the state and of a broad sector of society, it seemed that religious-based identities had definitely lost political importance and that religious aspects would be relegated to the private sphere. On the contrary, linguistic dynamics became increasingly important, as reflected in the development recently experienced in language regulations at the highest legal ranks (with more constitutional clauses referring to official, national, state, principal or native languages).

In the second half of the twentieth century, it seemed that in Europe religion, which had been a prominent source of division during the previous four centuries, was barely a hindering element in the public sphere, and that language had become the instrument of either national cohesion or division. However, population movements and other social transformations have caused religion to regain a public visibility that had seemed lost. The return of religion to the center of public debate has occurred in diverse circumstances, including a greater number and coexistence of religions and a much more complex panorama, featuring phenomena such as believing without belonging (Davie 2000) and belonging without believing (Hervieu-Léger 1993). Today, there is a livelier debate on the application of rights related to religious differences than to linguistic differences, despite the secularization process. At the same time, it has become accepted that diversity and a certain degree of division in society are healthy and consistent with the very idea of a democratic society ${ }^{2}$.

Therefore, both religious and linguistic differences remain factors that shape groups aspirations for public space. Both factors are relatively visible today, but at the same time, they are also difficult to apprehend and define. It is problematic to find a valid definition of religion that is generally accepted and can be adapted to all the phenomena experienced in our societies. It is also a major challenge to map out religious communities or groups. 
The definition of religion today must be necessarily broader and more comprehensive than those that have been traditionally provided ${ }^{3}$. Similarly, it is not always easy to define a language, to differentiate it from the category of dialect, or to establish linguistic elements that are symbolically and politically relevant, such as glossonyms or alphabets ${ }^{4}$.

In addition to the difficulties in defining and categorizing languages and religions, there are differences between these two identity factors in how they appear in the public sphere (and consequently in their relationship with the law). These differences can be classified as anthropological, sociological or legal.

In the western tradition, it is generally understood that individuals may be linguistically diverse, but this is not usually accepted in terms of religion. Thus, the same person can speak several languages or feel emotionally linked to more than one language, but presumably belongs to one religious tradition. This does not exclude the increasingly frequent tendency to syncretism, to the fusion of religious traditions and similar phenomena, but it is always considered that a single spirituality is professed, even if it may gather elements from various other traditions. Along the same lines, in the European context, religion is understood as a contingent element in people's lives, so being an atheist or non-religious is regarded as normal. On the contrary, the linguistic aspect is perceived as being necessary for the life of any individual, regardless of the format or version (for example, spoken language or sign language). This dichotomy is transferred to the public realm, which is usually stated to be neutral as a direct consequence of the democratic character of the state $^{5}$. However, the non-religious status of the state apparatus normally coexists with a seemingly inevitable commitment to one or more languages recognized as official, native, national or protected.

From the sociological point of view, language is often seen as a necessary instrument for socialization that can only be meaningful when it is shared interpersonally. On the contrary, religion is relegated to the private sphere and sometimes to a purely personal experience. This division has been widely and openly questioned by those who understand religion as a shared spiritual phenomenon that must be externally expressed. Likewise, in western societies we tend to consider that languages have a more compact or more certain territorial base, while religions can spread from one territory to another more easily and have a more uncertain geographical affiliation. But this vision can be called into question today, since the mobility seen in language can also be recognized in religion. This is particularly the case from the perspective of the so-called new minorities (lacking a traditional territorial basis), as their identity can be based on linguistic elements as well as on religious traditions. However, even if there are obviously some examples of traditional religious minorities and of non-territorial linguistic minorities, our current social majorities still tend to mentally relate linguistic diversity to a traditional diversity founded in regional or minority languages, while the idea of religious minorities in western Europe evokes groups composed mainly of immigrants.

On a legal level, from the very origin of the idea of human rights, freedom of religion and conscience has been recognized as a fundamental human right. This assumption has been included in all existing international human rights treaties, and today freedom of religion is undoubtedly a universally assumed right. So, it can be stated that religion is legally protected at the highest level by this basic freedom. On the contrary, there is no human right to language, beyond what freedom of expression may entail. Language is not in itself the direct object of any fundamental human right. Only people belonging to linguistic minorities have a recognized human right $^{6}$ to use their own language, but this is not extensible to every person, as it happens with respect to religion. Undoubtedly, this changes the way in which the law addresses diversity in each of these realms. But it is legitimate to ask ourselves how rational these differences are and to analyze whether a more parallel legal approach to these two major cultural elements that make up collective identities should be promoted.

These operational differences between religious and linguistic elements partly account for the fact that the study and dynamics of these areas have been separated. This does not 
mean that we cannot find examples of how religion and language have been interlinked. However, despite their importance in shaping collective identities, the relationship between language and religion has so far been little studied in general terms (Brubaker 2012; Zolberg and Woon 2010; Vijay Pandharipande et al. 2019). Similarly, the study of their legal treatment has been traditionally divergent, giving rise to fairly unrelated fields of analysis. However, the basis for the protection of both religion and language relates to people's dignity, so it is worth analyzing what techniques have been used for each of them and if the techniques used only for one of them can shed some light on the protection of the other. The usual means of protection of linguistic diversity may be beneficial for religious minorities.

\section{Differences in the Legal Dynamics of Both Elements}

From a legal and political point of view language and religion work very differently as factors for determining minorities. This is mainly due to two reasons, which provide the explanatory framework for the tensions and difficulties encountered in regulating them (Brubaker 2012, p. 3):

(a) The different involvement or connection of the public bodies with both identity factors.

(b) The substantive or instrumental character of the two identity markers.

Regarding the first reason, it is believed today that languages are necessary for the functioning of public institutions, while religions are not. Moreover, it is generally understood that, in democratic models, the state should be neutral in religious matters, but that it cannot and should not be neutral in the linguistic field. This leads to differentiated legal relations between the state (in its broadest sense) on the one hand, and languages and religions on the other.

As regards the second reason, while languages are fundamentally deemed to be instruments or codes for communication and, consequently, devoid of ideological, moral or normative content when they are used by the public apparatus, religions involve norms that may have an impact not only on the private life of their believers, but also on the organization of society and of the public space. Religions somehow entail ideological choices (Harari 2015, ch. 3.12) that translate into normative preferences that may have legal aspirations. However, as far as languages are concerned, the debate focuses on their preferential use or not by the public realm. This is why the choice of one language or another in principle does not affect the content of other rules of the legal system.

From the combination of these two reasons it can be deduced that, although there is a smaller overlap between religion and public institutions than there is between the latter and language, the practical consequences of the former are more difficult to manage, since they can result in a clash between regulatory systems. If we add to this the fact that technological advances, like immediate translation, will gradually diminish the impact of linguistic diversity, it can be easily concluded that the democratic management of religious diversity appears to be much more complex than that of linguistic diversity in the long term.

However, today many debates continue to focus on linguistic diversity, to the extent that languages are more closely linked to national (and therefore state) identities than religious identities. If one adopts the perspective of minority languages and religions as they are defined in state terms, the former have been more profusely studied in international law than the latter. On the contrary, under national law the protection of religious minorities is a cross-cutting issue in almost all formally democratic systems, while the protection of minority languages is only an important issue for constitutional law in some countries.

It can be argued that the legal treatment of religious and linguistic minorities has had little in common to date. Although both types of minorities are jointly recognised and their protected rights appear at the same time in the well-known Article 27 of the International Convenant on Civil and Political Rights (ICCPR) and in the Declaration on the Rights of Persons Belonging to National or Ethnic, Religious and Linguistic Minorities adopted 
by General Assembly in 1992, their protection has illuminated different and sometimes divergent fields.

The first legal difference lies in the fact that, under International Law (and Comparative Constitutional Law), freedom of religion is a universally recognized human right ${ }^{7}$, as well as a right of the members of religious minorities. However, there is no comparable right to a language, beyond the rights of linguistic minorities (which are very generic in nature). There is no freedom of language as such (a 'right to a language') in the same way as there is freedom of religion. This clearly changes the position of both elements in the political and regulatory game. Unlike religion, language is not in itself directly the object of a fundamental human right.

Following Ringelheim (2006, pp. 428-29), cultural diversity is also protected under human rights by the recognition that, in order to guarantee the effectiveness of a right for a person or a group of people, a certain cultural (minority) characteristic needs to be considered. This is understood, for example, in the right to a fair trial, when the accused does not adequately understand the trial language. But similar reasoning has been applied with regard to language as a requirement for (or an inherent element to) the effectiveness of the right to education ${ }^{8}$ (or other elements like a traditional (nomadic) home as an element for the effectiveness of the right of domicile ${ }^{9}$ ). This approach, unlike the previous one, usually protects the linguistic issue, although the religious issue cannot be completely ruled out from it.

In a similar vein, sometimes a cultural element can be considered to be inherent to the object of the protected right or a dimension of the right itself. This has been argued above all in relation to the right to engage in a traditional way of life as part of the right to private and family life under Article 8 of the ECHR, but also in relation to language. It has been based on the understanding that the right to education could include the right to instruct in one's own language ${ }^{10}$, and that freedom of expression includes the language used by people to express themselves ${ }^{11}$. By contrast, it is again difficult to apply this approach to the religious identity marker.

Minority languages and religions can also be protected by the application of the principles of material equality and non-discrimination. In particular, language and religion are two of the most commonly cited factors in constitutional clauses as possible discrimination grounds ${ }^{12}$ (Ruiz Vieytez 2020). In this case, protection would extend to both factors, although the consideration of when actual discrimination occurs in the two cases tends to be substantially different. It is easier to justify discrimination based on religious differences than on linguistic differences, since there is a necessary engagement of the public apparatus with certain official or preferred languages. This greater extent of protection of religious differences may in turn explain two findings. Firstly, while several authors provide doctrine about possible linguistic (human) rights (Grin 2005; Kymlicka and Patten 2003; May 2005; Skutnabb-Kangas and Philipson 1995), there is hardly any correlation in terms of theorizing about religious human rights, as religious differences appear to be better protected by the principle of non-discrimination. Secondly, while the so-called 'new minorities' are often included in the list of religious minorities without much difficulty, they are usually excluded from the protection granted to linguistic minorities ${ }^{13}$.

In short, the legal operations involved in the protection of each of these two factors have proven to be different, and sometimes divergent. In addition, technological evolution will seriously affect linguistic diversity, facilitating automatic translation and dramatically reducing its real operational impact, to the extent that at some point the protection of minority languages may be far less relevant in the future. However, no technological elements seem to suggest that religious differences may be irrelevant in the near future.

\section{Possible Contribution from the Minority Language Field}

As language and religion show differentiated social and legal dynamics their relationship with the law has developed separately. Different areas of legal doctrine have focused their efforts on these two scopes of protection. Although linguistic and religious 
minorities theoretically share legal instruments, it is still largely considered that they cannot be protected in the same way. This has led to little dialogue on how the means of protection used for linguistic minorities can be applied to religious minorities and vice versa.

As the aim of this paper is precisely to engage in this dialogue, I will analyze the set of legal instruments or techniques that somehow aid or participate in the policies for the democratic management of cultural diversity. This will make it possible to compare how these policies are at play with each of these identity markers and draw any relevant conclusions from that comparison. For the analysis, these instruments will be separated into two broad areas. Firstly, I will address what I call techniques for the constitutional arrangement of cultural diversity and, secondly, other techniques for the pluralization of rights. Both blocks converge at certain times, but the former provides a more collective, political-constitutional approach, while the latter focuses on the legal protection of individual rights. In other words, the analysis is more focused on law as a legal system in the first block of techniques, whereas it is centered on the exercise of rights in the second block.

\subsection{Techniques for the Constitutional Accommodation of Diversity (Cultural Minorities and the Law)}

Both religion and language are widely represented and regulated in European constitutions. Of a total of 50 European constitutions, religion is expressly cited in 48 of them and language in 44 , albeit in very different ways. In previous publications I have defined four major techniques used for diversity management in democratic states (see Figure 1; Ruiz Vieytez 2014, p. 23). Although both factors can be covered by the four approaches of the diagram, some differences between them are observed in practice. Territorial selfgovernment and recognition of official status are much more closely linked to linguistic diversity than to religious diversity, whereas consociationalism and power-sharing instruments operate in the reverse way. In contrast, the recognition of specific rights is used in the comparative constitutional landscape for linguistic and religious-based minorities in a more balanced manner. And yet, there are some examples of territorial self-government of religious differentiation and of the official status of religions or churches, just like some isolated examples can be found of personal autonomies or consociational arrangements with a predominantly linguistic basis.

\begin{tabular}{|c|c|c|}
\hline & $\begin{array}{c}\text { Collective approach } \\
\text { (Relations majority- } \\
\text { minorities) }\end{array}$ & $\begin{array}{c}\text { Individual approach } \\
\text { (Relations state-citizens) }\end{array}$ \\
\hline $\begin{array}{c}\text { Global approach } \\
\text { (Diversity as a defining } \\
\text { element of the State) }\end{array}$ & $\begin{array}{c}\text { Territorial } \\
\text { Self-government }\end{array}$ & $\begin{array}{c}\text { Recognition of } \\
\text { Official status } \\
\text { for minority elements }\end{array}$ \\
\hline $\begin{array}{c}\text { Partial approach } \\
\text { (Diversity as a } \\
\text { secondary element } \\
\text { within the State) }\end{array}$ & $\begin{array}{c}\text { Participation } \\
\text { Power-sharing } \\
\text { Cultural autonomy }\end{array}$ & $\begin{array}{c}\text { Specific rights } \\
\text { for members of minorities }\end{array}$ \\
\hline
\end{tabular}

Figure 1. Systematization of legal-constitutional techniques for accommodating diversity within a State.

1. Territorial-based self-government. The rationale for almost all territorially based constitutional arrangements is diversity management related to linguistic differences (or language-based ethnic or national differences). Self-government enables mechanisms that include the granting of official status, a special level of recognition to the language or languages concerned, or territorially limiting certain linguistic rights to an autonomous territory. Little of all this applies to the religious sphere, except for some ethnic-national differences that have a religious rather than a linguistic basis and can be translated into 
territorial self-governments. In Europe, this situation is only found in some autonomous republics of Russia, Azerbaijan and Georgia, the territorial units of Bosnia-Herzegovina and the Swiss federal division. It could seem more far-fetched to include the cases of Scotland and the very particular case of Mount Athos, in Greece. The use of territorial self-government as a mechanism for managing religious diversity is very limited nowadays.

2. Personally or culturally-based self-government. Examples of personally or culturallybased self-government (autonomy recognized to groups as such and not as citizens of a territorial polity) where the main distinctive element is religion are more frequent. A contributory factor is the fact that many forms of personal self-government may co-exist within the same territory. On this basis, in addition to establishing special representation and financing mechanisms for diverse religious groups, more flexible formulas can be articulated to make private law (especially family law, education and cultural production) compatible with different religious beliefs. The main obstacle for this technique is the secular refusal encountered in many western countries to divide the population across religious lines, since religions are deemed to be part of the private realm. This leads to these techniques always being applied indirectly through organizations, churches or similar bodies. This mechanism already exists, but its potential in western European societies has not yet been sufficiently explored (Nimni 2005) ${ }^{14}$.

3. Consociationalism and power sharing This mechanism also includes the possibility of applying quotas in representative or decision-making institutions. Again, the political culture of western European countries makes it difficult to apply these types of solutions, even though there are specific mechanisms in some European countries based on language groups (South Tyrol, Belgium, Cyprus; de facto in Finland or Switzerland). The application of these techniques to religion-based groups is very rare in the West. The exceptions are the dual cases of Cyprus and Northern Ireland, where there are 'political communities' rather than 'religious affiliations.' These techniques are designed to satisfy a relationship between a small number of communities. They face difficulties in complex societies where there is co-existence of multiple religious affiliations that are not always perfectly defined.

4. Consultative or participatory bodies. Although it is a technique derived from the previous technique, its features allow for a broader, more flexible application. It applies to both language and religion-based diversities, and examples of both can be found. An advisory council of confessions poses difficulties regarding its composition but serves as a buffer for the absence of a more formal relationship between the public apparatus and religious minorities' demands for public space.

5. Official status. While there are some European states that have official or quasiofficial churches (United Kingdom, Denmark, Greece, and Norway until 2017), it is assumed that the democratic nature of a state requires it to be neutral in religious matters. This practically renders this technique useless as an instrument to manage a broad religious diversity. It is undoubtedly the instrument most typically used for linguistic diversity management, but a transfer of the linguistic to the religious realm seems very complicated. In addition, many aspects of the official assumption of languages by the states are also questionable, since it is not clear on what criteria the states may confer legal categories to different languages and, therefore, different rights to their speakers. These difficulties would be also applicable and more evident in the religious sphere.

6. Categorization of protection by levels. A mechanism derived from the previous one involves establishing partial categorizations between non-recognition and officialization of a certain identity feature. In some countries this applies to languages, but also to religions, confessions and/or their organizations. Categorizing confessions and adopting policies based on these categories, as sometimes is the case with languages, can be useful for managing and protecting religious diversity. The most important obstacle is that this categorization will also have to be made compatible with the principle of nondiscrimination, which demands providing objective and reasonable criteria for applying differences between the various religious groups. 
7. Recognition of specific rights or rights for specific groups. Many constitutions recognize a series of specific rights for persons belonging to minorities. In the case of European constitutions, it can be verified that most of these rights are linked to linguistic or identity issues in the broad sense. On the contrary, hardly any references can be found to the 'religious rights' of people belonging to religious minorities. This is probably due to the differing conceptions of what the public apparatus involvement should be in the protection of these minorities. However, the conclusion of some agreements between states and religious organizations may also include the recognition of some specific rights for these groups. In this respect, while it is considered that the protection of linguistic minorities requires the state's active intervention for the adoption of positive measures, it is normally understood that religious diversity can be sufficiently protected through abstention and respect, something that is questionable. This is one of the fields in which there is room for greater development in the religious realm, taking as a basis the specific or explicit rights that various legal systems have recognized for linguistic-based minorities.

8. Recognition of rights through the incorporation of international law. Sometimes states ensure the recognition of rights to protect linguistic or religious minorities by ratifying international treaties or by linking principles incorporated into international documents. This technique falls within a category of international law that can be called minority law. It can be stated today that there is an increasingly solid legal framework on the protection of minorities, at least in Europe. It is composed of specific international treaties that have already been ratified by a large number of states ${ }^{15}$, concrete clauses of general human rights treaties ${ }^{16}$, institutions specifically established with a mandate in this area ${ }^{17}$, and a set of non-strictly binding political documents (soft-law) ${ }^{18}$ that are becoming more and more established. However, the application of this law is severely constrained, not only by the need for ratification (in the case of international treaties), but also by how each state interprets of the concept of minority. In this way, some states in Europe, such as France, Greece and Spain, refuse to accept that there are national minorities within them and therefore do not apply all or some of the rules provided in this regulatory sector.

As a matter of fact, minority law is a normative block that can protect both religious and linguistic minorities, as evidenced by the wording of Article 27 of the ICCPR. However, the scope of application is usually different in each case. In general, it protects old and new minorities in the religious case, but not in the linguistic one. At the same time, protection aimed at linguistic diversity demands greater intervention from the public sector than is provided for religious diversity. It is also important to note that there are no treaties or documents specifically dedicated to religious diversity, while there are some in relation to linguistic diversity. The main exponent of this is the 1992 European Charter for Regional or Minority Languages (hereinafter ECRML), as well as other non-directly binding documents. Although this treaty largely aims to protect a cultural heritage and not the rights of speakers, it acts as a set of objective rules for the protection of linguistic minorities in the countries where it is applied. And it does so by using a system of compromise options which must be adopted and adapted to the situation of each of the protected languages by each State. This is precisely one of the legal protection avenues thus far unexplored in the field of religious diversity in which the linguistic realm could provide fresh inspiration.

\subsection{Techniques for Pluralization in the Application of Rights (Rights and Cultural Minorities and the Law)}

Shifting from a political-constitutional perspective to an approach focused on the protection of human rights, there is another group of techniques or instruments that seek to provide a positive response to cultural diversity. Basically, these options work on the interpretation of the rights already recognized and their implementation in order to effectively include the cultural (linguistic or religious) dimension. The analysis of these techniques or instruments could shed additional light on whether some that have been used with greater or lesser success in the linguistic field could also be reasonably extended to the religious field. 
9. Cultural reinterpretation of content. As it has been noted, operational differences between language and religion are also materialized in how rights are defined. While religion is in itself the object of a fundamental human right, language is not. However, as it has been said before, language is sometimes conceived as a fundamental element to guarantee the effectiveness of another right or is considered to be inherent to the object of another right. On the contrary, religion does not seem to be accepted as contributing to the effectiveness of, or being inherent to, other rights. The debates always refer to respect for freedom of religion or to the right of persons belonging to religious minorities to profess their own religion.

A possible consequence of this could be reinterpreting rights, by considering religion as a substantial element in certain rights or a necessary aspect for the effectiveness of other rights. It is worth asking whether the approach used for language could also be applied for religion. If religious identity is deemed to be part of a person's dignity, there should be a sphere within some rights that should be obligatorily respected when the religious identity of an individual is affected. This has been argued in relation to the right to education, freedom of expression, the right to a name and the right to employment. Ultimately, it is not so much a question of referring any debate on religious identity to respect for freedom of religion, but of bringing a cross-cutting approach to religion with respect to the rest of fundamental rights, similarly to the way in which it is timidly done with language.

10. Multicultural clause. Following the previous line of argument, the proposed reinterpretation would be equivalent to the mandate of a 'multicultural clause' for the interpretation of rights in constitutions. The only clear example in comparative constitutional law is Section 27 of the Canadian Charter of Rights and Freedoms, approved as an annex to the Constitution in 1982, which reads as follows: 'This Charter shall be interpreted in a manner consistent with the preservation and enhancement of the multicultural heritage of Canadians.' It is, in fact, a constitutional clause, but it is included in this second block of techniques because the Canadian case is the only one really existing, and its application would be equivalent to how rights are already partially reinterpreted for language in some respects. It is also directly related to the reinterpretations resulting from the principle of equality and non-discrimination, which are analyzed below.

Section 27 of the Canadian Charter of Rights and Freedoms has not been widely used in the application of the rights recognized by the Constitution (Gall 2002; Magnet 2005). It serves as a hermeneutical guideline and is an inspiring principle which helps to consider the cultural identity of people when determining conflicts of rights or interests. However, the relationship of this clause to other constitutional provisions that recognize specific rights for certain minorities based on historical arguments has not been unequivocally resolved. For some time, Canada has been faced with the problem of accommodating more recent religious minorities that aspired to receive treatment equal to that given to other traditional religious minorities. And the provision in Section 27 has not proven to be particularly useful for this purpose ${ }^{19}$. It is also true that the scope of linguistic rights in Canada to date escapes the legal force that this clause can encompass. A similar clause or one that is specifically oriented to respect the multireligious heritage of a given society is an instrument that should be considered. The effect of such a clause should further the interpretation provided in the preceding section.

11. Reasonable accommodation. Reasonable accommodation is a corollary of the principle of non-discrimination and consists in the legal obligation to take measures to harmonize an action or inaction with a particular demand to exercise a right, unless it causes an undue hardship. It can be specified in the repeal of or exception to a certain norm, or in its adaptation or particular arrangement in time, in space or in a certain activity. The reasonable accommodation technique does not come from an express regulatory formulation, but from a jurisprudential conception of the right to equality developed by US and Canadian Courts (Bosset 2007, p. 10). Reasonable accommodation, therefore, can be used on any of the fundamental rights in a legal system, including those that rely on or are based on cultural elements, such as the specific case of freedom of religion or expression ${ }^{20}$. 
In reality, reasonable accommodation has been profusely used and studied in the protection of religious minorities. However, it remains to be used in the field of linguistic diversity, where it could yield interesting results, this being in the opposite direction to the area of interest of the analysis conducted here.

12. Indirect discrimination. The prohibition of discrimination is included among the most basic universally recognized rights in any democratic system. Virtually all legal systems incorporate a clause that specifically prohibits discrimination, and many of them refer to linguistic or religious elements as potential grounds of discrimination ${ }^{21}$. Its adjectival form (discriminatory) can also appear in various ways ${ }^{22}$.

In the field of cultural diversity, the concept of indirect discrimination has great potential $^{23}$, since sometimes allegedly neutral norms or practices end up causing a particularly harmful effect to a certain group (religious or linguistic). On other occasions, it is precisely the lack of differentiation (either in the norm itself or in its application) that causes indirect discrimination. This gives rise to the concept of 'discrimination by non-differentiation' or 'discrimination by equalisation' (Rey Martínez 2008), used by the European Court of Human Rights since $2000^{24}$, specifically in relation to religious difference.

The principle of non-discrimination affects the two areas studied here. So far, indirect discrimination has been applied more often to the religious realm than to the linguistic realm. Therefore, while it is useful and still to be developed, it offers more potential from the religious sphere to the linguistic one than it does in the opposite direction.

13. Religious human rights. Although the existence of 'linguistic rights' or even 'linguistic human rights' is sometimes mentioned, no theories have been developed on 'religious human rights' independent of freedom of religion or of the right of religious minorities to profess their faith. It is worth asking whether religious diversity can be better protected by creating a set of 'religious (human) rights', and whether this would actually add new content to the protection already contained in the two rights mentioned above.

When discussing possible religious human rights, we refer to options and powers already listed under and covered by freedom of religion. But the usual block of 'linguistic rights' is clearly aimed at demanding intervention from public administrations by adopting positive or political measures. Therefore, it could make sense to explore a list of rights that might be enforceable by public administrations to guarantee the religious diversity of a society, going beyond a generous interpretation of freedom of religion. If (some) linguistic rights can be considered human rights and not specifically linked to a given group, then an analogy could be established with the religious field, since freedom of religion is generally recognized, opening the door to a possible list of religious human rights not specifically linked to concrete groups. However, in several legal systems, religious rights are actually recognized only for certain religious groups based on a specific declaration or on concepts such as 'deeply-rooted religions'. At this point, this development needs to be linked to the application of the principle of non-discrimination.

14. Cultural heritage protection. It can be argued that, as it is the case for linguistic diversity, minority religions should be legally protected as components of a cultural or social heritage that must be preserved and guaranteed. The clearest example of this approach in the linguistic field is the ECRML. The point here would be to create legal instruments that, like the ECMRL for minority languages, would protect minority religions, opening the door to rights that could be exerted by their believers. In this way, religious rights would appear as the outcome of the protection of cultural diversity, which in this case is religious in nature. This would translate into a set of rights or powers aimed at protecting the wealthy existence of minority religions in the society, as the ECRML does on the linguistic level.

\section{Conclusions}

Religious and linguistic minorities have so far received very uneven legal protection in European countries. In addition, this protection has been largely based on different legal arguments. This has been greatly motivated by the fact that freedom of religion 
appears in the first declarations of rights, while the maintenance and use of a language has not been considered a human right in itself, but only accorded to members of certain linguistic minorities. This leads to the fact that, in the case of religious minorities, it is difficult to distinguish which is the added scope of protection for the right of members of religious minorities with respect to the freedom of religion of all persons. It is even difficult to determine which religious groups can be qualified and treated as religious minorities, as freedom of religion is recognized in every democratic State. On the contrary, in the case of language, only linguistic minorities who have had certain rights recognized can exercise them by using their own language in the public realm. This tends to be restricted to traditional minorities, closing the way to new diversity, unlike what has been the case at the religious level.

Thus, it is challenging to transfer techniques or instruments for the protection of linguistic to religious diversity and vice versa. However, this exercise is necessary in societies that must manage cultural diversity in a more inclusive and democratic way, regardless of their origin. When considering the transfer of minority protection techniques or instruments from the linguistic to the religious level, two options are ruled out from the start. On the one hand is the application of official status, because it is considered that the state must be neutral in the religious sphere (which also means questioning the categorizations used in some states to recognize religious minorities at the expense of others). On the other hand is the application of the principle of territoriality, as it fails to adapt to the current European reality in which religious differences no longer correspond to a clear geography, but to multicultural urban environments. Once these two options have been discarded, the focus will be placed on three major avenues.

The first of these is the way to develop specific rights in the religious realm that can be declared and recognized nationally or internationally. This would involve developing elements inherent to freedom of religion (or to the right of religious minorities), expressing rights enforceable by public authorities and their adoption of positive measures, as in the case of the so-called linguistic rights. In the international scope, this could be materialized in the adoption of a treaty that protects religious expressions in various aspects of public, social and cultural life. These might even be considered as a menu of commitments, so that states can adapt their obligations to the changing religious diversity of each society. This instrument would consist of a (European) Charter for minority religions or similar documents of principles and criteria for the management of religious diversity, widening and developing the protection offered today in Europe by some of the articles of the Framework Convention for the Protection of National Minorities. At state level, this route could crystallize in the recognition of 'religious minority rights' (parallel to linguistic rights) in the Constitution or in enacted legislation. In this way, these rights would be guaranteed and would require the public authorities to put in place resources and policies for their effective protection, instead of merely refraining from intervention.

A complementary or alternative route to the previous one is that of generic rights, understanding religion as a part of the essential content of a right when it is enjoyed or exercised by a person whose religious identity is not the same as the majority's. Since it has already been recognized that language can be an effective or an essential element in the right to a fair trial or to education, the same could happen with religion, as religious identity can constrain the effectiveness of other fundamental rights. The right to marriage, the right to employment, to freedom of expression, or the right to receive information can and should be reinterpreted from multicultural perspectives, so that they can be enjoyed by all people through their identity and not in spite of it. This identity sometimes includes the religious factor, as has often been recognized for the linguistic element. This exercise is necessary for the democratic management of cultural diversity. It involves furthering the principle of non-discrimination, which results in techniques such as reasonable accommodation or the option of a multicultural clause. In reality, they are a consequence of assuming indirect discrimination in all its potential. 
A final option is that of considering religions as a cultural heritage, whose value is necessary and fair to protect. Under this interpretation, the initial aim is not to protect the rights of people who profess a minority religion, but rather minority religions themselves, insofar as they are part of the cultural heritage of our diverse societies. This leads to the need for the public domain to commit to take concrete actions for their protection and development. Again, the most telling example is that of the ECMRL, not so much as an itemized list of rights, but as a way of protecting religious diversity, understood as a valuable cultural heritage of European societies. This would complement and improve the level of protection that can be offered today by the Framework Convention for the Protection of National Minorities, which is not technically contemplated as a treaty for cultural protection. In this respect, a proposal is made here to adopt an international treaty that would undertake this task and that could subsequently be ratified by the European states, with a follow-up mechanism that would help protect the different religious minorities.

Finally, in addition to strict legal viewpoints, it would be desirable to transfer the current debate on linguistic justice (De Schutter 2007; Mowbray 2012; Alcalde 2015; Van Parijs 2011; Castiglione and Longman 2007) to the plane of religious diversity. This discussion seeks to determine how to establish the fairest relations between languages, considering all the implications they have for the enjoyment of rights. Issues such as the application of public resources proportionally or on equal terms, special support for minority languages, and setting greater quotas for speakers of majority languages are raised to this end. In fact, this debate can be extended to any of the elements that make up cultural identities in diverse societies, religion or religious tradition possibly being the most obvious one. Thinking about cultural justice (including the relationships between religious denominations) in parallel to what is currently being discussed on linguistic justice would help to improve the legal mechanisms for the protection of religious minorities and the democratic management of religious-based diversity.

Funding: This research received no external funding.

Conflicts of Interest: The author declares no conflict of interests.

\section{Notes}

A symbolic starting point is the Villers-Cotterêts Ordinances, adopted by Francis I of France in 1539.

ECHR: case Bessarabian Metropolitan Church v. Moldova, application no. 45701/99, judgement of 13 December 2001, for 119; case Refah Partisi v. Turkey, applications nos. 41340/98, 41342/98, 41343/98 and 41344/98, Judgment of 31 July 2001, para. 69; case Agga v. Greece, applications nos. 50776/99 and 52912/99, Judgment of 17 October 2002, para. 58-60.

3 For the United Nations Human Rights Committee it is necessary to broaden the idea of religion in order to incorporate new phenomena that do not match the great religious traditions. UN Human Rights Committee, The right to freedom of thought, conscience and religion (Article 18) (General Comment no. 22), adopted on 30 July 1993 (UN Doc CCPR/C/21/rev.1/Add. 4), paragraph 2.

4 The identification of alphabets with language and religion has turned the former into a strong identity factor in some diversity contexts.

5 On religious neutrality of the public bodies, the UN Human Rights Committee has stated that 'limitations on the freedom to manifest a religion or belief for the purpose of protecting morals must be based on principles not deriving exclusively from a single tradition'. UN Human Rights Committee, General Comment No. 22: Article 18 (Freedom of Thought, Conscience or Religion), 30 July 1993, United Nations doc. CCPR/C/21/Rev.1/Add.4, para. 8. This reasoning, however, does not apply to the language realm; a 'linguistic neutrality' of states is not considered a must.

6 For instance, Article 27 of the International Covenant on Civil and Political Rights (1966) and Article 30 of the Convention of the Rights of the Child (1989).

7 The right to freedom of thought, conscience, religion and belief represented one of the consolidated universal human rights according to internationallLaw standards (Article 18 of the Universal Declaration of Human Rights, and Article 18 of the ICCPR). In addition, the UN General Assembly adopted in 1981 the Declaration on the Elimination of all forms of Intolerance and Discrimination based on religion or belief: United Nations, General Assembly, Resolution 36/55 'Declaration on the Elimination of All Forms of Intolerance and Discrimination Based on Religion or Belief', 25 November 1981.

8 ECHR, case Cyprus v. Turkey, application no. 25781/94, Judgment of 10 May 2001.

9 ECHR, case Chapman v. United Kingdom, application no. 27238/95, Judgment of 18 January 2001. 
10 ECHR, case Cyprus v. Turkey, application no. 25781/94, Judgment of 10 May 2001, para 275-278.

11 UN Human Rights Committee, case Ballantyne, Davidson, McIntyre v. Canada, communications nos. 359/1989 and 385/1989, U.N. Doc. CCPR/C/47/D/359/1989 and 385/1989/Rev.1 (1993), of 5 May 1993.

12 In Europe, out of 50 states, 39 constitutions include listings of potential discrimination factors. In the 39 listings, references to religion are included (it is the most cited factor of all clauses), and 27 include references to language. Other factors overwhelmingly cited are sex, visible phenotypic traits, opinions or convictions, and origin (Ruiz Vieytez 2020).

13 For example, this is established by Article 1.a. of the European Charter for Regional or Minority Languages (1992).

14 A full debate on cultural or personal autonomy can be found in the special issue 1/2013 of the Journal on Ethnopolitics and Minority Issues, available online: http:/ / www.ecmi.de/publications/detail/issue-12013-273/ (accessed on 6 March 2021).

15 The Framework Convention for the Protection of National Minorities (1995) and the European Charter for Regional or Minority Languages (1992).

16 Like Article 27 of the International Covenant on Civil and Political Rights (1966) and Article 30 of the Convention of the Rights of the Child (1989).

17 Like the OSCE High Commissioner on National Minorities.

18 The UN Declaration on the Rights of Persons Belonging to National or Ethnic, Religious and Linguistic Minorities, adopted by General Assembly Resolution 47/135, of 18 December 1992, or the different Recommendations provided by the OSCE High Commissioner on National Minorities, available online: https:/ /www.osce.org/hcnm/thematic-recommendations-andguidelines (accessed on 6 March 2021).

19 This can be seen in the comparison between the Adler case at the domestic level and the Waldman case at the international level, leading to divergent decisions by the Canadian Supreme Court and the United Nations Human Rights Committee: Supreme Court of Canada, Adler v Ontario case, [1996] 3 SCR 609, Judgment of 21 November 1996; Human Rights Committee, Waldman v Canada case, Decision of 3 November 1999 (United Nations doc. CCPR/C/67/D/694/1996).

20 According to the Supreme Court of Canada, when a law pursues a valid secular objective, but also involves restrictive effects on the freedom of religion of some people, they have the right to obtain accommodations, usually in the form of a waiver of the application of the law, provided that such a solution is compatible with public interest and does not cause undue hardship. Supreme Court of Canada, Ontario Human Rights Commission versus Simpsons-Sears, [1985] 2 SCR 536, Judgment of 17 December 1985; R. v. Edwards Books and Art Ltd., [1986] 2 Supreme Court Review 713, p. 32, Judgment of 18 December 1986.

21 Vid. supra, footnote 12.

22 A taxonomy of discrimination concepts can be found at the United Nations Committee on Economic Social and Cultural Rights, Non-discrimination in ESC Rights (General Comment no. 20), adopted on 10 June 2009 (United Nations doc. E/C.12/GC/20).

23 Introduced in European Law by Council Directive 2000/43/EC, of 29 June 2000, implementing the principle of equal treatment between persons irrespective of racial or ethnic origin, OJ L 180/22; Council Directive 2000/78/EC, of 27 November 2000, establishing a general framework for equal treatment in employment and occupation, OJ L 303/16. ECHR, case Thlimmenos v. Greece, application no. 34369/97, Judgment of 6 April 2000.

\section{References}

Alcalde, Javier. 2015. Linguistic Justice: An Interdisciplinary Overview of the Literature. Amsterdam Working Papers in Multilingualism 3: 27-96. [CrossRef]

Bosset, Pierre. 2007. Les fondements juridiques et l'évolution de l'obligation d'accommodement raisonnable. In Les accommodements raisonnables: Quoi, comment, jusqu'où? Des outils pour tous. Edited by Myriam Jézéquel. Cowansville: Éditions Yvon Blais, pp. 3-28.

Brubaker, Roger. 2012. Language, religion and the politics of difference. Nations and Nationalism 19: 1-20. [CrossRef]

Castiglione, Dario, and Chris Longman, eds. 2007. The Language Question in Europe and Diverse Societies. Political, Legal and Social Perspectives. Oxford and Portland: Hart Publishing.

Darquennes, Jeroen, and Wim Vandenbussche. 2011. Language and religion as a sociolinguistic field of study: Some introductory notes. Sociolinguistica Internationales Jahrbuch für Europäische Soziolinguistik/International Yearbook of European Sociolinguistics/Annuaire International de la Sociolinguistique Européenne 25: 1-11. [CrossRef]

Davie, Grace. 2000. Religion in Modern Europe: A Memory Mutates. Oxford: Oxford University Press.

De Schutter, Helder. 2007. Language policy and political philosophy: On the emerging linguistic justice debate. Language Problems and Language Planning 31: 1-23. [CrossRef]

Gall, Gerald L. 2002. Jurisprudence under section 27 of the Charter: The second decade. The Wilson Yearbook on Access to Justice 21: 307-30.

Grin, Francois. 2005. Linguistic human rights as a source of policy guidelines: A critical assessment. Journal of Sociolinguistics 9: 448-60. [CrossRef]

Harari, Yuval Noah. 2015. Sapiens: A Brief History of Humankind. London: Vintage books.

Hervieu-Léger, Danièle. 1993. The Religion Pour Mémoire. Paris: Éditions du Cerf. 
Kymlicka, Will, and Alan Patten. 2003. Language Rights and Political Theory: Context, Issues, and Approaches. In Language Rights and Political Theory. Edited by Will Kymlicka and Alan Patten. Oxford: Oxford University Press, pp. 1-51.

Magnet, Joseph Elliot. 2005. Multiculturalism and Collective Rights. The Supreme Court Law Review 27: 431-97.

May, Stephen. 2005. Language Rights: Moving the debate forward. Journal of Sociolinguistics 9: 319-47. [CrossRef]

Mowbray, Jacqueline. 2012. Linguistic Justice: International Law and Language Policy. Oxford: Oxford University Press.

Nimni, Ephrain, ed. 2005. National Cultural Autonomy and Its Contemporary Critics. Oxford: Routledge.

Rey Martínez, Fernando. 2008. La discriminación múltiple, una realidad antigua, un concepto nuevo. Revista Española de Derecho Constitucional 84: 251-83.

Ringelheim, Julie. 2006. Diversité Culturelle et Droits de l'homme. The Protection des Minorities for the Convention Européenne des Droits de l'homme. Brussels: Bruylant.

Ruiz Vieytez, Eduardo. 2014. Cultural Diversities and Human Rights: History, Minorities, Pluralization. The Age of Human Rights Journal 3: 1-31.

Ruiz Vieytez, Eduardo. 2016. Cultural traits as defining elements of minority groups. The Age of Human Rights Journal 7: 6-28. [CrossRef]

Ruiz Vieytez, Eduardo. 2020. Cláusulas antidiscriminatorias y motivos de discriminación en las constituciones europeas. Revista de Derecho Político 107: 41-69. [CrossRef]

Skutnabb-Kangas, Tove, and Robert Philipson, eds. 1995. Linguistic Human Rights. Overcoming Linguistic Discrimination. Berlin and New York: Mouton de Gruyter.

Van Parijs, Philippe. 2011. Linguistic Justice for Europe and for the World. Oxford: Oxford University Press.

Vijay Pandharipande, Rajeshwar, Maya Khemlani David, and Miriam Eisenstein Ebsworth, eds. 2019. Language Maintenance, Revival and Shift in the Sociology of Religion. Bristol: Multilingual Matters.

Williams, Glyn. 1992. Sociolinguistics. A Sociological Critique. London: Routledge.

Zolberg, Aristide R., and Long Litt Woon. 2010. Why Islam is like Spanish: Cultural Incorporation in Europe and the United States. Politics E Society 27: 5-38. 